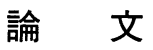

|IIIIIIIIIIIIIIIIIIIIIIII

\title{
荒廃林地における窒素集積の形態ならびに 生物窒素固定とその役割について
}

嶋 一徹*・宝珠山恭子*・千葉喬三*

\section{Nitrogen Accumulation and Contribution of Biological Nitrogen Fixation in a Waste Forest}

\author{
Shima, Kazuto*, Housyuyama, Kyoko*, Chiba, Kyozo* \\ 要旨
}

花崗岩地帯に位置する荒廃林地において窒素の集積形態および生物窒素固定活性（アセ チレン還元活性) を調査した。その結果、全窒素集積量は $70.9 \mathrm{~g} \cdot \mathrm{m}^{-2}$ であり, 植生の発達 にともない地上部のみならず土壌においても集積量が増加していた。しかし, 堆積した有 機物における窒素固定活性はわずかであった。生物窒素固定の約 $90 \%$ は植生が未発達で表 土の露出した場所に群体を形成するラン藻，およびそれらが菌類と共生した地衣類によっ て行われており, 調查地全体の生物窒素固定量を理論的換算率を用いて推定すると, 215.43 $\mathrm{mgN}_{2} \cdot 80 \mathrm{~m}^{-2} \cdot \mathrm{day}^{-1}$ であった。これらラン藻による固定活性は表土が極端な乾燥条件にお かれても, 灌水を行えば約12時間で回復した。荒廃林地においても適当な環境条件下では 相当量の生物窒素固定が行われており, 窒素の確保以外に多くの要因が植生回復を困難に しているものと思われた。

\section{1. 緒言}

瀬戸内沿岸の花崗岩地帯には山火事等の翼乱を受けた 後に放置されている荒廃林地が多数みられるが，それら の植生回復には窒素の確保が必須である。窒素は養分循 環からみれば比較的閉鎖的な循環をする自己施肥系であ るが, 生態系内への主要な供給源は生物窒素固定である と考えられている (Bormann and Likens，1985)。

植生の発達した森林では林木の根圏 (Richards, 1973) や分解過程の植物遺体 (Nioh，1980；Roskoski，1980； O’ Connell et al., 1979）などにおいて非共生的窒素固定 が起こることが報告されている。しかし，これら単生窒 素固定生物は環境条件の影響を受けやすく，また固定活 性の発現には多量の炭素源が必須であり, C-N 比の高い 森林土壤などを除けば窒素供給源としての役割はほとん ぞないものと考えられる(中村，1980)。このため有機物

\footnotetext{
* 岡山大学農学部

Fac. of Agric., Okayama Univ.
}

集積に乏しい治山造林地では宿主植物からエネルギー源 を獲得できる共生窒素固定が重要な役割を果たし, 早期 緑化と林地における窒素の確保を図る目的で古くから肥 料木が植栽されてきた。

これに対して放置されている荒廃林地では, 植生回復 が非常に遅く, 攪乱後10数年が経過しても依然裸地に近 い状況を呈している場所もみられる。これらにおける窒 素の確保には光合成能力をもち, 生育範囲がきわめて広 いラン藻が重要な役割を果していることが予想される (山口, 1980)。しかし, これまで荒廃林地における生物 窒素固定に関しては詳細な検討は行われておらず, どの ような形態で窒素の確保が図られているのかについては 明らかでない。そこで, 花崗岩地帯の荒廃林地において, 窒素の集積形態と生物窒素固定活性について調査を行っ た。

\section{2. 調査地の概況}

調查は岡山市南部の児島半島に位置する貝殼山（標高 
$287 \mathrm{~m}$ ) の北西斜面中腹部 (平均傾斜 $24^{\circ}$ ) で行った。調査 地付近は花崗岩を母岩としており，山火事によって植生 が失われたのち放置されている荒廃林地である。植生の 発達はきわめて乏しく，木本類はサイズの小さいクロマ ツやネズミサシなどが疎らにみられる程度であり，樹高 が $3 \mathrm{~m}$ を超えるものはほとんどみられない。また，地表 は部分的にシダ類の群落で覆われているが，残りは表土 が侵食され，母岩の風化した砂磔質土壤が露出していた。

調査地付近では度重なり山火事が発生しているため現 在の植生がいつ頃から成立したのかは明らかでない。し かし, 比較的サイズの大きいクロマツおよびネズミサシ 各10本について地際付近の年輪数を調べた結果, 山火事 後20〜24年程度が経過しているものと推測された。

\section{3. 調査方法}

1990年 6 月に調査地に $8 \times 10 \mathrm{~m}^{2}$ のプロットを設けて 以下の調查および測定を行った。

\section{1 地上部の現存量}

木本類は全出現樹種について地際直径および樹幹長を 測定したのち伐倒して，樹幹，枝，および葉に区分して それぞれ生重を測定した。また, シダ類の群落について はプロット内の任意の 5 個所に $0.5 \times 0.5 \mathrm{~m}^{2}$ の方形区を 設け，地上部を刈り取り生重を測定した。これら刈り取 り試料はその一部を持ち帰り $105^{\circ} \mathrm{C} て ゙ 72$ 時間乾燥させて 絶乾率を求めるとともに CN コーダー（柳本 TM-500 型）により全炭素扔よび全窒素の含有率を測定し, 調査 地における現存量を推定した。

3.2 地下部の現存量と生物窒素固定活性

地表における有機物の堆積状態や藻類および蘇苔類な ぞの生育状況は均一でなかった。このためプロット内の 数地点から採取した試料から地下部における窒素の集積 や固定活性を検討することは不可能であると判断され た。そこで，まずはじめに地表の状況を詳細に把握する ためにプロットを $0.1 \times 0.1 \mathrm{~m}^{2}$ メッシュに区分して,1) シ ダ類の群落によって被覆されているか，2)有機物の堆積 がみられるか，3) 菌類と共生した地衣を含め, ラン藻の 明暸な生育群落が認められるかを調べた。これをもとに 調査プロットの地表被覆区分図を作成し, シダ群落によ って被覆されている地表部分 (以下, 植生被覆区分とす る。) と表土が露出している地表部分 (同, 表土露出区分) に区分し，窒素集積量および窒素固定活性を調べた。

1）表土露出区分

表土露出区分においては地表に生育する地衣類や藻類 なぞを砂磁や分解の進んだ有機物から完全に分離するこ とは困難な状況であった。そこで金属製円筒（断面積 50 $\mathrm{cm}^{2}$, 長さ $5.0 \mathrm{~cm}$ )を用いて, 深さ $5 \mathrm{~cm}$ までの表土を䚓 乱しないように採取した。試料の採取は地表の状況に応 じて,有機物が堆積している個所からランダムに16地点, および堆積がみられず表土の露出する個所から 35 地点の 合計51地点で行った。また，表土の露出する個所のうち， 14地点はラン藻の明暸な群体が認められる個所であり, 残り21地点はこれらの明暸な生育が認められない個所で あった。

採取試料は深さ $1 \mathrm{~cm}$ までの表層部分とそれ以外の土 壤部分に区分して，窒素固定活性および全炭素，全窒素 含有率の測定に供した。このうち, 表層部分については 滤紙を敷いたシャーレに試料を摫乱しないように置き， 十分な量の蒸留水を灌水したのち， $30^{\circ} \mathrm{C}$ 恒温室に 24 時 間静置してから，窒素固定活性の測定を行った。また， 土裹部分については試料をよく混合したのち，その約 10 $\mathrm{g}$ を取り出して表層部分と同様に窒素固定活性の測定を 行った。

窒素固定活性の測定はアセチレン還元法(吉田, 1977) を用いて行った。試料は $200 \mathrm{ml}$ 容のフラスコに入れシリ コン栓で密封したのち，ガス拡散を図るために真空ポン プで減圧してから，濃硫酸および蒸留水で順次洗浄した アセチレンを気相の $10 \%$ 注入した。そして，再び空気を 徐々に注入し大気圧に戻してから， $30^{\circ} \mathrm{C}$ 恒温室に 24 時 間静置（暗条件 8 時間，6000 lux の明条件16時間）した のち, フラスコ内の気相を十分拡散させてから，その 400 $\mu 1$ をガスタイトシリンジで採取して生成されたエチレ ン量をガスクロマトグラフ（島津 GC-9A 型，FID 検出 器）によって測定した。本研究ではアセチレン注入後 24 時間に生成されたエチレン量をもってアセチレン還元活 性 $\left(\mathrm{C}_{2} \mathrm{H}_{4} \mu\right.$ moles $\cdot \mathrm{m}^{-2} \cdot$ day $\left.^{-1}\right)$ とした。

また, 各試料はアセチレン還元活性測定後, $\mathrm{CN}$ コーダ 一により全室素および全炭素含有率を測定した。

2) 植生被覆区分

植生被覆区分においてはシダ群落の生育密度および地 表の有機物堆積状況がほぼ均一であった。そこで地上部 現存量を測定した 5 力所の方形区において，堆積する有 機物および深さ $20 \mathrm{~cm}$ までの土壌と根系をそれぞれ採 取した。そして, 各方形区ごとにリターおよび根系は $5 \mathrm{~g}$ づつ，また土壤は深さ $5 \mathrm{~cm}$ までの表土とそれ以外に区 分して各 $10 \mathrm{~g}$ づつの $3 \sim 8$ 試料を取り出し,アセチレン 還元活性および全炭素, 全窒素含有率の測定を行った。

\section{3 表土の乾燥が窒素固定活性におよほすす影響}

表土の乾燥が窒素固定活性におよほすす影響を調べるた めに，プロット内で顕著なアセチレン還元活性が認めら れた地点から, 深さ $1 \mathrm{~cm}$ までの表層土壌を摫乱しない 
ように採取したのち, $30^{\circ} \mathrm{C}$ の温風下に50時間以上放置し て含水率 $5 \%$ 未満の状態に風乾させた。この風乾試料はア セチレン還元活性が認められなくなったのを確認したの ち, 十分な量の滅菌蒸留水を灌水した。そして, 灌水直 後および $30^{\circ} \mathrm{C}$ 恒温室に 24 時間静置(暗条件 8 時間, 6000 lux の明条件16時間)したのちに, それぞれアセチレン還 元活性を測定し，灌水後の活性回復を調べた。

\section{4. 結果および考察}

\section{1 植生および地表の状態}

調査地の植生発達は非常に乏しく, 瀬戸内沿岸の花崗 岩地帯における典型的な荒廃林地の様相を呈していた。 木本類の全出現本数は 17875 本・ha ${ }^{-1}$ であったが, それら はいずれもサイズが小さく, 地際直径は平均 $18.8 \mathrm{~mm}$, 樹幹長は平均 $87.7 \mathrm{~cm}$ であった。また, 地際断面積合計は $6.46 \mathrm{~m}^{2} \bullet \mathrm{ha}^{-1}$ であるが, そのうちクロマツ(Pinus Thunbergii) が $68.0 \%$, ネズミサシ (Juniperus rigida) が $10.2 \%$, そしてコバノミツバツツジ（Rhododendron reticulatum) が7.8\%をそれぞれ占めていた。
つぎに木本類以外の植生および地表の状況をみるため に，被覆区分図を図 1 に，また各被覆区分ごとの面積を 表 1 にそれぞれ示した。調査プロットの地表の $62.0 \%$ は コシダ (Dicranopteris dichotoma) をわずかに混生した ウラジロ (Gleichenia japonica) の群落に被覆された植 生被覆区分であった。この区分では地表に 2〜 $4 \mathrm{~cm}$ 程度 の厚さでシダ類やクロマツなどのリターが堆積するとと もに, 分解の進んだ有機物や表土には部分的に藻類や蘇 苔類なども認められた。

これに対して, 残りの $38.0 \%$ の地表は表土露出区分で

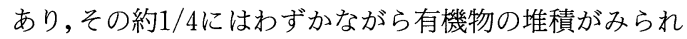
るものの, それ以外は母岩の風化した砂碟質土壌が露出 していた。また, この区分の $9.5 \%$ の地表にはラン藻が痂 状に群体を形成, もしくは菌類と共生した地衣として明 暸な生育が認められた。

\section{2 窒素の集積状況}

調査プロットにおける窒素集積状況を表 2 に示した。 地上部を含めた深さ $20 \mathrm{~cm}$ までの全窒素集積は $70.90 \mathrm{~g} ・$ $\mathrm{m}^{-2}$ と少なく, 植生発達がそしいために, その 9 割が地下

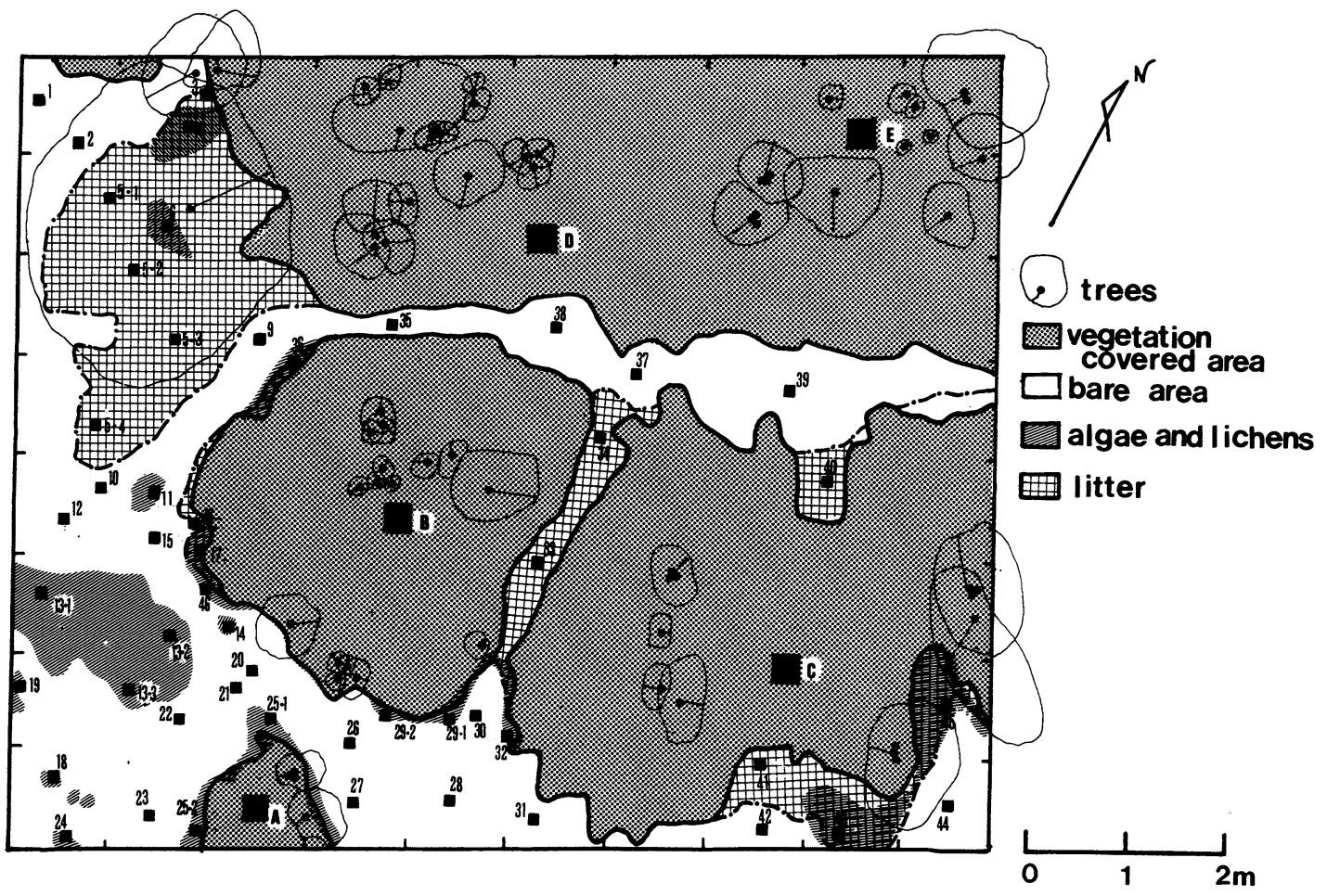

図 1 調査地の地表面被覆状況

Fig. 1 Map of investigated plot showing the ground surface condition

Legend: $\mathbf{\square}$, Sampling point 
表 1 調査プロットの地表面の状況

Table 1 The ground surface condition of investigated plot

\begin{tabular}{llll}
\hline \multirow{2}{*}{$\begin{array}{c}\text { Vegetation } \\
\text { cover }\end{array}$} & \multicolumn{1}{c}{$\begin{array}{c}\text { Classification of the ground } \\
\text { surface condition } \\
\text { Covitter) }\end{array}$} & $\begin{array}{c}\text { Algae crusts } \\
\text { or lichens }\end{array}$ & $\begin{array}{c}\text { Surface area } \\
\left(\mathrm{m}^{2}\right)\end{array}$ \\
\cline { 2 - 3 } Covered area & Accumulated & - & $49.6(62.0)$ \\
\hline Bare area & Accumulated & Colonized & $0.2(0.2)$ \\
& Not accumulated & Colonized & $7.3(9.2)$ \\
& & Not difined & $2.7(3.4)$ \\
\hline Whole & & & $20.2(25.2)$ \\
\hline
\end{tabular}

Note: Figures in parenthesis show percentages.

表 2 調査プロットにおける全窒素集積量

Table 2 Total nitrogen accumulation in investigated plot

\begin{tabular}{lccc}
\hline Fraction & $\begin{array}{c}\text { Vegetation } \\
\text { covered area } \\
\left(\mathrm{Ng} \cdot \mathrm{m}^{-2}\right)\end{array}$ & $\begin{array}{c}\text { Bare area } \\
\left(\mathrm{Ng} \cdot \mathrm{m}^{-2}\right)\end{array}$ & $\begin{array}{c}\text { Whole } \\
\left(\mathrm{Ng} \cdot \mathrm{m}^{-2}\right)\end{array}$ \\
\hline Above ground & $11.36(13.3)$ & $0.51(1.1)$ & $7.23(10.2)$ \\
Trees & 5.16 & 0.51 & 3.39 \\
Fern and grasses & 6.20 & 0.00 & 3.84 \\
\hline Below ground & $73.90(86.7)$ & $47.08(98.9)$ & $63.67(89.8)$ \\
Litter & 7.49 & 1.00 & 5.02 \\
Roots ( 0 $20 \mathrm{~cm}$ depth) & 2.85 & 0.53 & 1.97 \\
Soil $0 \sim 5 \mathrm{~cm}$ & 27.00 & 11.76 & 21.17 \\
$\quad 5 \sim 10 \mathrm{~cm}$ & 16.55 & 13.79 & 15.50 \\
\hline Total $20 \mathrm{~cm}$ & 20.01 & 20.00 & 20.01 \\
\hline
\end{tabular}

Note: Figures in parenthesis show percentages.

部における集積であった。また，地表における植生発達 は均一でなく, その有無によって地上部現存量のみなら ず地表の状況にも大きな相違がみられた。有機物の堆積 量をみると植生被覆区分では $943 \mathrm{~g} \cdot \mathrm{m}^{-2}$ であるのに対 して, 表土露出区分では $154 \mathrm{~g} \cdot \mathrm{m}^{-2}$ であった。有機物の 堆積にともない土裹における窒素含有率にも増加がみら れ, 深さ $0 \sim 5 \mathrm{~cm}$ の表層土壌における平均窒素含有率は 植生被覆区が $0.075 \%$ あるあのに対して, 表土露出区分で はわずか $0.029 \%$ でった。

このため単位面積あたりの窒素集積量をみると, 地上 部は表土露出区分が $0.51 \mathrm{~g} \cdot \mathrm{m}^{-2}$ であるのに対して, 植生 被覆区分では22.3倍の $11.36 \mathrm{~g} \cdot \mathrm{m}^{-2}$ であった。また, 深さ $20 \mathrm{~cm}$ までの全窒素では表土露出区分が $47.59 \mathrm{~g} \cdot \mathrm{m}^{-2}$ で あるのに対して，植生被覆区分では 1.8 倍の $85.20 \mathrm{~g} \cdot \mathrm{m}^{-2}$ であった。これに両区分の面積（表 1 ）を掛け，プロッ ト内の集積量を求めると全体の $74.5 \%$, 地上部では
$97.4 \%$ が植生被覆区分に集積されていた。

このように荒廃林地における窒素の集積は非常に乏し く, しかも地上部における植生発達の有無によって集積 量には大きな相違がみられた。

\section{3 窒素固定活性（アセチレン還元活性）}

各地点におけるアセチレン還元活性を比較するまえ に，堆積する有機物および表層土を対象にアセチレン注 入後の時間経過にともなうエチレン生成量の変化を図 2 に示した。ラン藻の共生する地衣類のいくつかではアセ チレン注入後約 4 時間程度のごくわずかな停滞時間が認 められた。しかし，それ以外の試料ではエチレン生成量 が時間経過にともなってほぼ直線的に増加していた。ま た，これら各試料についてアセチレンを注入しないコン トロールを設けて内生的エチレン生成の有無（中村, 1980）を調べたが，いずれも定量可能なエチレンの生成 は認められなかった。これより本研究においては, アセ 


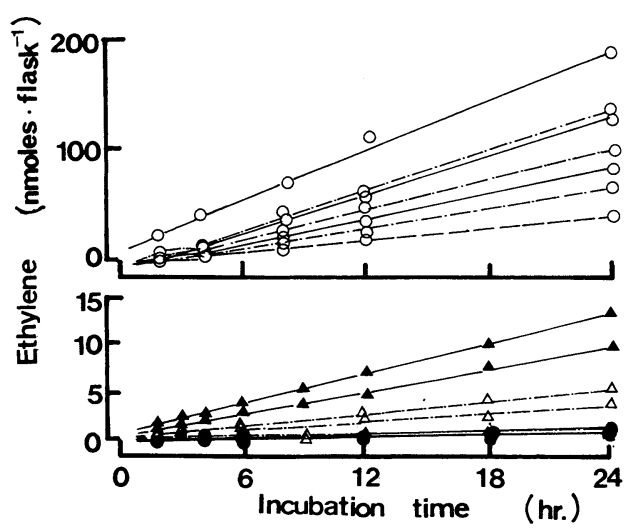

図 2 アセチレン注入後の時間経過にともなうエチレン 生成量の変化

Fig. 2 Time courses of acetylene reduction by surface soil and litter

Legend: $\bigcirc$, Algae crusts or lichens occurred on bare area

$\boldsymbol{\Delta}$, Surface soil of vegetation covered area

$\triangle$, Leaf litter accumulated on vegetation covered area

- Leaf litter accumulated on bare area

チレン注入 24 時間後のエチレン生成量をもってアセチレ

ン還元活性を比較することに問題はないと判断された。

つぎに地表の各被覆区分ごとのアセチレン還元活性お

よび全活性に占める各被覆区分の貢献度合を表 3 に示し

た。

表土露出区分をみると，アセチレン還元活性が認めら れたのはいずれもラン藻の生育が認められる地点の表層
部分のみであり，深さ $1 \mathrm{~cm}$ 以下の土壌部分では全く活 性が認められなかった。しかし，その活性は地表の状況 によって大きく異なっていた。

このうち最も高い活性が認められたのは, 有機物堆積 のない地表にラン藻の明暸な群体が認められた区分であ り，その活性は平均 $756.91 \mu \mathrm{moles} \cdot \mathrm{m}^{-2} \cdot \mathrm{day}^{-1}$ であっ た。しかし, 調查地点によって活性には大きな相違がみ られ, ラン藻が群体ないしは地衣体として高密度に生育 する地点（No. 13・1〜 13・3, No. 19）では $2000 \mu$ moles・ $\mathrm{m}^{-2} \cdot \mathrm{day}^{-1}$ 以上の非常に高い活性が認められたのに対 して, 降雨にともなう侵食により地衣体の一部が流亡し て疎らになっている地点（No. 11，14，29・1～29・2）や 地表面に降雨による砂礫堆積がみられた地点（No. 32, $25 \cdot 2)$ などでは $10 \mu \mathrm{moles} \cdot \mathrm{m}^{-2} \cdot \mathrm{day}^{-1}$ 未満の活性しか認 められなかった。また, ラン藻を分離して観察すると, その多くはへテロシストをもつ Nostoc sp. であったが, これ以外にもへテロシストをもたないラン藻が数地点で 分離された。

また，有機物の堆積に加えて明暸なラン藻群体も認め られなかった区分においても平均 $8.89 \mu \mathrm{moles} \cdot \mathrm{m}^{-2}$. $\mathrm{day}^{-1}$ の活性が認められた。ここでも活性には地点間の 差異が大きく, 表土の侵食による浅い溝やわずかな凹地 形にラン藻が疎らに生育する地点 (No. 21〜23, 26, 27) では $10 \mu \mathrm{moles} \cdot \mathrm{m}^{-2} \cdot \mathrm{day}^{-1}$ 以上の活性が認められたの に対して, 母岩の露出する地点 (No. 37, 38) や最近の 降雨にともない砂礫が堆積した地点 (No.9, 10, 39) で は全く活性が認められなかった。これより表土露出区分 における公素固定の大半がラン藻によるものであるが, その活性はラン藻の生育密度に加えて地表の物理的な環

表 3 地表面区分によるアセチレン還元活性の違いと窒素固定における貢献度

Table 3 Difference in acetylene reduction activity and percentage contribution to total $\mathrm{N}_{2}-$ fixation activity of ground surface condition

\begin{tabular}{|c|c|c|c|c|c|c|}
\hline \multirow{2}{*}{$\begin{array}{l}\text { Vegetation } \\
\text { cover }\end{array}$} & \multicolumn{2}{|c|}{ The ground surface condition } & \multirow{2}{*}{$\begin{array}{l}\text { Number of } \\
\text { sampling } \\
\text { point } \\
\left(\mathrm{No}^{\circ} \text { plot }^{-1}\right)\end{array}$} & \multirow{2}{*}{ 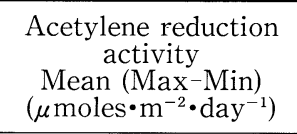 } & \multirow{2}{*}{$\begin{array}{c}\mathrm{N}_{2}-\text { fixation } \\
\text { activity of } \\
\text { plot }(\mathrm{mgN} \cdot \\
\left.80 \mathrm{~m}^{-2} \cdot \text { day }^{-1}\right)\end{array}$} & \multirow{2}{*}{$\begin{array}{c}\text { Percentage } \\
\text { contribution to } \\
\text { total } \mathrm{N}_{2} \text {-fixation } \\
\text { activity }(\%)\end{array}$} \\
\hline & $\underset{\text { (Litter) }}{\text { Organic matter }}$ & $\begin{array}{l}\text { Algae crusts } \\
\text { or Lichens }\end{array}$ & & & & \\
\hline $\begin{array}{l}\text { Vegetation } \\
\text { covered area }\end{array}$ & Accumulated & & $5^{1)}$ & $49.16(102.65-24.76)$ & 22,76 & 10.57 \\
\hline \multirow{4}{*}{ Bare area } & \multirow{2}{*}{ Accumulated } & Colonized & 9 & $9.74(20.93-1.06)$ & 0.02 & $<0.01$ \\
\hline & & Not defined & 7 & $0.96(\quad 1.43-0.00)$ & 0.07 & 0.03 \\
\hline & \multirow{2}{*}{ Not accumulated } & Colonized & 14 & $756.91(5194.18-0.86)$ & 190.90 & 88.61 \\
\hline & & Not defined & 21 & $8.89(123.41-0.00)$ & 1.68 & 0.78 \\
\hline Whole & & & 56 & $185.96(5194.18-0.00)$ & 215.43 & 100.00 \\
\hline
\end{tabular}

Note: 1) In each sampling points, acetylene reduction activity of forest floor, soil and roots were measured for 3-9 samples respectively. 
表 4 植生被覆区分におけるアセチレン還元活性

Table 4 Acetylene reduction activity of vegetation covered area

\begin{tabular}{ccccc}
\hline \multirow{2}{*}{$\begin{array}{c}\text { Sampling } \\
\text { point }^{1)}\end{array}$} & \multicolumn{2}{c}{ Acetylene reduction activity ${ }^{2)}$} & \multicolumn{2}{c}{$\left(\mu\right.$ moles $^{*} \mathrm{~m}^{-2} \cdot$ day $\left.^{-1}\right)$} \\
\cline { 2 - 5 } & Litter & Roots & $0-5 \mathrm{~cm}$ soil & $5-20 \mathrm{~cm}$ soil \\
\hline A & $1.627(1.381)$ & $0.455(0.025)$ & $100.571(11.101)$ & $<0.01$ \\
B & $10.947(0.695)$ & $0.439(0.130)$ & $35.721(13.005)$ & $<0.01$ \\
C & $1.363(0.032)$ & $0.265(0.098)$ & $22.757(9.029)$ & $<0.01$ \\
D & $1.163(0.395)$ & $0.352(0.126)$ & $27.447(16.778)$ & $<0.01$ \\
E & $1.503(0.203)$ & $0.465(0.173)$ & $40.743(8.822)$ & $<0.01$ \\
\hline
\end{tabular}

Note : 1) Abbreviation of sampling point are same as Fig. 1.

2) Standard deviations of mean are given in parenthesis.

境が大きく影響を及ぼすものと考えられた。

次に植生被覆区分をみると活性は平均 67.94 moles・ $\mathrm{m}^{-2} \cdot \mathrm{day}^{-1}$ であり, ラン藻の明暸な群体がみられた区分 に次いで高い活性が認められた。そこで, 表 4 に堆積有 機物, 根系抢よび土畩における活性を各方形区ごとに示 した。いずれの方形区でも全活性の大半は深さ $0 \sim 5 \mathrm{~cm}$ の表土部分における活性であった。これに対して堆積す る有機物における活性は1.16〜10.95 $\mu$ moles $・ \mathrm{~m}^{-2}$ • $\mathrm{day}^{-1}$ の範囲であったが，これを乾重あたりになおすと 3.07〜9.18 moles $\cdot \mathrm{m}^{-2} \cdot \mathrm{day}^{-1}$ となり，スギ林（Nioh, 1979）やユーカリ林（O' Connell et al., 1979）などの林 床有機物層における非共生窒素固定活性に比べるとかな り低い值であった。また，イネ (Yoshida and Ancajas, 1971) やトウモロコシなどの畑作物 (Dommergues et al., 1973）に加えて熱帯草本類 (Maasdrop，1987) などでは, 根圏において単生窒素固定生物と穏やかな共生関係をも つ共同窒素固定が認められる。しかし，本調査ではいず れの根系試料の活性も非常に低く, 共同窒素固定に関し ては確認できなかった。また，これら植生被覆区分にお いて顕著な活性が認められた表土などを詳しく観察する と, 表土露出区分と同様にラン藻の生育が認められた。

このように地表の被覆状況の違いにかかわらず，顕著 な活性が認められたのはラン藻の生育する表土部分であ ることから, 主要な窒素固定生物はラン藻であると考え られた。しかし, 各区分における窒素固定活性に従属栄 養生物が関与する可能性についても検討を行う必要があ る。そこで, 表土露出区分の地衣が生育する地点と侵食 による凹地にラン藻が生育する地点, および植生被覆区 分の表土部分を対象に明条件 (6000 lux) と暗条件 ( lux）でアセチレン還元活性を比較した結果を図 3 に示 した。

いずれも明条件で顕著な活性が認められたのに対し， 暗条件では培養開始後 24 時間が経過しても明条件の1/

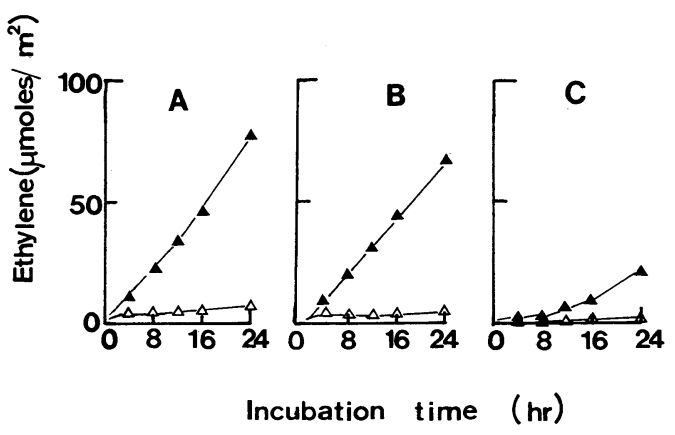

図 3 光条件が地表のアセチレン還元におよぼす影響

Fig. 3 Effects of incubation time on ethylene reduction of surface soil under light and dark conditions

Legend: $\triangle$, Dark condition ( $\leqq 10$ lux.)

$\boldsymbol{\Delta}$, Light condition (6000 lux.)

Note: A, Lichens occurred on surface soil of bare area

B, Algae crusts occurred on vegetation covered area

C, Algae crusts occurred on bared area

15〜1/17程度のエチレン生成量しか認められなかった。 また，これ以外の試料についても図 3 と同様の結果が得 られたことから, 本調査地における窒素固定が従属栄養 生物ではなく独立栄養生物によることが確認された。

つぎにアセチレン還元活性から理論的換算率 $\mathrm{C}_{2} \mathrm{H}_{4}$ ： $\mathrm{N}_{2}=3 ： 1$ を用いて, プロットの全窒素固定量を推定し た。このうち表土露出区分でラン藻の明暸な群体が認め られる地点については, 各地点ごとにその群体の面積と 活性から推定を行った。また, それ以外については各被 覆区分ごとに求めた地表の面積と単位面積あたりの平均 活性からそれぞれ推定を行った。

その結果，プロットにおける深さ $20 \mathrm{~cm}$ までの全窒素 固定量は $215.43 \mathrm{mg} \cdot 80 \mathrm{~m}^{-2} \cdot \mathrm{day}^{-1}$ と推定された。これ 
は光，水分および温度を適当な条件に設定して測定した アセチレン還元活性をもとに推定された值である。野外 における年間の固定量を推定するためには,さらに多く の環境要因とその変動について検討を加える必要があ り, 今回の結果から単純に推定することはできない。し かし, 適当な環境条件下では, $2.69 \mathrm{mg} \cdot \mathrm{m}^{-2} \cdot \mathrm{day}^{-1}$ 程度の 窒素固定が行われており, 特に表土露出区分の明暸なラ ン藻の群体では $70.7 \mathrm{mg} \cdot \mathrm{m}^{-2} \cdot \mathrm{day}^{-1}$ という非常に高い 窒素固定が行われていると推定された。

森林における非共生窒素固定量を推定した報告をみる と, 落葉広葉樹林の分解過程のクリ (Castanea dentata) 枯死樹幹で $0.89 \mathrm{~kg} \cdot \mathrm{ha}^{-1} \cdot \mathrm{yr}^{-1}$ (Cornaby and Waide, 1973)，スギ林の落葉リターで $2.8 \mathrm{~kg} \cdot \mathrm{ha}^{-1} \cdot \mathrm{yr}^{-1}$ (Nioh, 1987), そしてユーカリ林の落葉リターで 38～257 mg・ $\mathrm{m}^{-2} \cdot \mathrm{yr}^{-1}\left(\mathrm{O}^{\prime}\right.$ Connell and Grave，1987）の範囲である。 これらと比較すると, 有機物および窒素の集積が非常に そしいにも関わらず, 本調查地において相当量の窒素固 定が行われているといえよう。

また, 全窒素の約 $3 / 4$ は植生被覆区分に集積されていた が, 生物窒素固定の約 9 割は表土露出区分で行われてお り, その大半は地衣を含めたラン藻生育地点において行 われていた。すなわち, 本調查地においては植生発達に ともなって窒素の集積がみられたのに対して、生物窒素 固定の大半は植生の未発達な表土で行われていたわけで ある。

肥料木を植栽した治山造林地を除けば, 森林では林床 有機物層において顕著な窒素固定活性が認められる (Nioh, 1979 ; O’ Connell et al., 1979 ; Roskoski, 1980)。これは従属栄養生物による窒素固定に多量の炭素 源の確保が必須であり(丸山，1976)，そのエネルギー源 を分解過程の林床有機物に依存しているためと考えられ ている。これに対して表土露出区分では有機物の集積が ごくわずかであり，しかもリターによるこれらの供給も ほとんど期待できない。このためエネルギー源をみずか ら確保できる独立栄養生物以外に窒素固定を行うことが 困難な状況であり, 生育範囲が広く比較的環境条件の劣 悪な所でも生育できるラン藻（山口，1980）が窒素固定 にとって大きな役割を果たすのであろう。これに対して 植生被覆区分では相当量の有機物が堆積しているにも関 わらず，アセチレン還元活性は低く，またその大半が表 土に生育するラン藻によるものと推測された。林床有機 物における単生窒素固定は炭素率の高い有機物の集積と ともに水分環境が大きな影響を及ぼし（Baker and Attiwill, 1984 ; Jurgensen et al., 1984), ユーカリ林では 温度条件が良好であってもリターの乾燥する時期には活
性がゼロ近くまで減少する (O' Connell and Grove, 1987)。荒廃林地では有機物の堆積がみられたとしても, 森林におけるそれと比べるとはるかに乾燥状態にある。 このため単生窒素固定生物が堆積する有機物において重 要な役割を果たすためには植生発達にともない林床の環 境条件がさらに改善される必要があるのかもしれない。

また，ラン藻の生育状況をみると植生被覆区分では分 解過程の有機物や表土に痂状の群体を形成していたが, 表土露出区分ではそれに加えて菌類と共生した地衣類も 多数みられた。ラン藻による窒素固定活性の発現にも環 境要因の影響は大きく, 野草地表面では水分条件が最も 重要な要因であると考えられた(Yoshida, 1984)。また, Nostoc sp. の場合には, 窒素固定活性の最適照度が 3000 〜 4000 lux 程度であり (Granhall, 1970)，積雪下の照度 500〜600 lux でも活性が認められるという報告（Englund and Meyerson，1974）もある。このため植生被覆 区分においては表土の乾燥が抑えられ，ラン藻の窒素固 定にとって好ましい光条件を作り出している (Yoshida, 1984)のかもしれない。これに対して表土露出区分では， 極端な乾燥に加えて, 夏期には日中の地表温度が $40^{\circ} \mathrm{C}$ 以 上に達することもしばしば観察されるなど環境条件が厳 しい。このため菌類と共生した地衣が重要な役割を果た しているのかもしれない。この点に関しては生育してい るラン藻や地衣類と環境条件との関係をさらに検討する 必要がある。

\section{4 乾燥後の灌水が窒素固定活性におよぼす影響}

窒素固定の大半が行われていた表土露出区分では，数 日間降雨がみられない場合には表層土壤が極端に乾燥す るのに対して, わずかな降雨でも樹冠による遮断がない ために水分が供給され, その環境は大きく変動する。そ こで，水分環境が窒素固定活性におよぼす影響を検討す るために，極端な乾燥によりアセチレン還元活性がみら れなくなった地表に灌水を行い, その後の活性の回復状 態を調べた結果を図 4 に示す。

各試料に十分な灌水を行い 24 時間培養したのちにアセ チレンを注入した場合, エチレン生成量が時間経過にと もない直線的に増加し，顕著なアセチレン還元活性が認 められた。これに対して十分な灌水を行った直後にアセ チレンを注入した場合には，その後12時間が経過したの ちにエチレン生成が認められ，約18～20時間でほぼ活性 が回復したと判断された。すなわち，地表が極端な乾燥 状態にある場合でも，降雨などにより水分条件が改善さ れると, その後 12 時間程度で活性が回復を始めると考え られた。

しかも, 活性の回復に要する時間は, ラン藻が単独で 


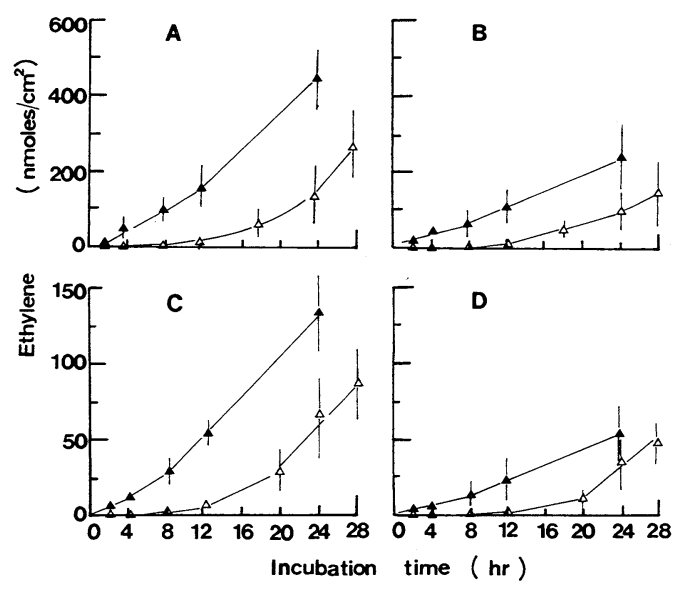

図 4 乾燥後の灌水がラン藻のアセチレン還元におよぼ す影響

Fig. 4 Effect of re-watering on the recovery of acetylene reduction (ethylene production) of algae crusts and lichens

Legend: $\triangle$, After re-water, acetylene was added immediately.

$\boldsymbol{\Delta}$, Incubated for 24 hours after re-water and acetylene was added.

Note: $\quad \mathrm{A}$ and $\mathrm{B}$, Lichens occurred on bare area. $\mathrm{C}$ and $\mathrm{D}$, algae crusts occurred on surface soil.

Each sample used in this experiment were previously air-dried up to about $5 \%$ (dry matter base) of water content at $30^{\circ} \mathrm{C}$ and re-watered the sterilizing water.

痂状に生育する場合でも菌類と共生する地衣の場合でも 顕著な相違が認められなかった。これより，乾燥後の活 性回復が地衣体を形成するか否かにかかわらず，ラン藻 自身の耐乾燥性によるものではないかと推測された。ま た，野草地表に生育するNostoc sp. を含水率 $2 \%$ 未満ま で風乾させた場合，灌水後 3 時間程度で活性が速やかに 回復したという報告がみられる（Yoshida，1984）。本調 査地では, これよりも活性の回復に長時間を要したが, その違いにはラン藻の種類や生育環境が考えられる。し かし，今回の調査結果からは明らかでない。

\section{5. おわりに}

花崗岩地帯の荒廃林地における窒素集積形態と生物窒 素固定活性を調查した。最近の山火事後すでに20～24年 が経過すると推測されたにもかかわらず本調查地の植生 は乏しく，しかもその分布は均一でなかった。そして， 植生発達にともなって地上部のみならず表土においても
窒素集積が認められた。これに対して生物窒素固定はそ の大半が植生の未発達な表土において独立栄養生物であ るラン藻により行われており，堆積した有機物における 固定活性は非常に低かった。今後, 生物窒素固定の形態 が独立栄養から従属栄養へと変化することも予想される が，それには植生発達にともなう有機物の集積とともに 林床における環境条件の改善が必要であると思われた。

また, 本調査地のような荒廃林地でも適当な環境条件 下では相当量の窒素固定が行われていると推定された。 これより本調査地では, 表土露出による土壌の極端な乾 燥および降雨にともなう侵食や栄養塩類の流亡など, 窒 素の確保以外にも多くの要因が植生回復を困難にしてい ることが予想された。

\section{引用文献}

1) Baker, G. and Attiwill, M.: Acetylene reduction in soil and litter from pine and eucalypt forests in south-eastern Australia. Soil Biol. Biochem., 16(3) : 241-245, 1984

2) Bormann, F. H. and Likens, G. E. : Pattern and process in a forested ecosystem. Springer-Verlag, New York : pp. 253, 1981

3) Cornaby, B. W. and Waide, B. J. : Nitrogen fixation in decaying chestnut logs. Plant Soil 39 : 455-448, 1973

4) Dommergues, Y. et al., : Non-symbiotic nitrogen fixation in the rhizosphere of rice, maize and different tropical grasses. Soil Biol Biochem. 5 : 83-89, 1973

5) Englund B., and Meyerson H., : In situ nitrogen fixation at low temperatures. OIKOS $25: 283-287,1974$

6) Granhall, U.: Acetylene reduction by blue-green algae isolated from Swedish soil. OIKOS 21 : 330-332, 1970

7) Jurgensen, F. et al., : Nitrogen fixation associated with increased wood decay in douglas-fir residue. Forest Sci., 30(4) : 1038-1044, 1984

8) Maasdrop, B. V.: Contribution of associative $\mathrm{N}_{2}{ }^{-}$ fixation (Acetylene reduction) in some grass-land ecosystems in ZIMBABWE. Biol. Biochem., 19(1) : 712,1987

9）丸山芳治：生物による窒素固定, 農化50(5)：121-132, 1976

10）中村道徳編：生物空素固定，学会出版センター, 東京： pp. 313,1980

11) Nioh, I. : Nitrogen fixation associated with the leaf litter of japanese cedar (Cryptomeria japonica) of various decomposition stages. Soil Sci. Plant Nutr., 26(1) : 117-126, 1979

12) Nioh, I. : Estimate of the amount of asymbiotically fixed nitrogen in the leaf litter of japanese cedar (Cryptomeria japonica), J. Jpn. For. Soc, 68: 314-319, 1986

13) O' Connell, A. M. and Grove, S. : Seasonal variation in $\mathrm{C}_{2} \mathrm{H}_{2}$ reduction $\left(\mathrm{N}_{2}\right.$ fixation) in the litter layer of eucalypt forest of southwestern Australia. Soil Biol. 
Biochem. 19(2) : 135-142, 1987

14) O' Connell, A. M. et al : Nitrogen fixation in the litter layer of eucalypt forests. Soil Biol. Biochem. $11: 681$ -682, 1979

15) Roskoski, J. P. : Nitrogen fixation in hardwood forest of the northeastern united states. Plant and soil $\mathbf{5 4}: 33$ $-44,1980$

16）山口益郎：生物の生産機能の開発 II. 生物窒素固定, 生物の生産機能の開発研究成果報告書編集委員会, $185-$ 195, 1980
17）吉田富男：アセチレン還元法, 土壤微生物研究会編土壌 微生物実験法：302-308, 養賢堂, 東京, 1977

18) Yoshida, T. : Algae nitrogen fixation in grassland. J. Japan Grassl. Sci., 30(2) : 145-150, 1984

19) Yoshida, T. and Ancajas, R. R. : Nitrogen fixation by bacteria in the root zone of rice. Soil Sci. Am. Proc., 35 : 156-158, 1971

(1992. 1. 13 受理)

\section{Summary}

Nitrogen fixation activity (ARA) in a wasted forest was determined by using the acetylene reduction technique. In the investigated plot, $62 \%$ of the ground surface was covered by vegetation, but $38 \%$ of that was bared. In the vegetation covered area, about $75 \%$ of total nitrogen and $98 \%$ of above ground nitrogen was accumulated respectively. While $0.94 \mathrm{~kg} \cdot \mathrm{m}^{-2}$ of litter was accumulated, ARA of that was lower in vegetation covered area. As a compare with that, the significant ARA of blue-green algae occurred in the surface soil of bared area.

Total nitrogen fixation was estimated to be $215.43 \mathrm{mgN}_{2} \cdot 80 \mathrm{~m}^{-2} \cdot \mathrm{day}^{-1}$ in the investigated plot with the theoretical conversion ratio $3: 1$, and about $89 \%$ of total fixation was in bare area. The recovery of ARA after re-watered of air-dried (below $5 \%$ of moisture content based on dry matter) surface soil was investigated. It was recognized the recovery of ARA was started about 8-hrs after re-watered in algaes and lichen. 